\title{
Correction to: The Devil Returns. Practices of Catholic Exorcism in Argentina
}

\author{
Verónica Giménez Béliveau
}

\section{Correction to:}

Chapter 5 in: G. Giordan, A. Possamai (eds.), The Social Scientific Study of Exorcism in Christianity, Popular Culture, Religion and Society. A Social-Scientific Approach 3, https://doi.org/10.1007/978-3-030-43173-0_5

Due to an oversight accents were missed to add in the name of the chapter author. Accents have now been added in this revised version and the name of the chapter author now appears as Verónica Giménez Béliveau.

The updated online version of this chapter can be found at https://doi.org/10.1007/978-3-030-43173-0_5 